permission or a special permit for scientific purposes, is one of the chief aims of the League, and this has already been adopted by fifty-two counties and subcounties in England and Wales. From 1925, the whole of the expenses were met by the founder.

\section{Mathematical Films}

IN connexion with the note in NATURE of December 31, p. 1151, Mr. Stefan Bergmann writes to point out how films might be used to illustrate the theory of functions of two complex variables. Each complex variable may be represented as a point in a plane, requiring two dimensions, so two such variables require four dimensions. We may obtain these by taking three dimensions in space and one in time, in fact by making a film showing a solid body the dimensions of which vary with the time. Full details were given by Mr. Bergmann some years ago ( $J$. deutsch. Mathematiker Verein., 42, 238 ; 1932-33), but so far as we are aware no such films appear in current lists of those available for sale or hire.

\section{Nutrition and Local Government}

THE Children's Minimum Council, 72 Horseferry Road, London, S.W.1, has issued a pamphlet entitled "Nutrition and Local Government-What Your Isocal Authority Can Do" (by Marjorie E. Green. Price 3d.). Although changes in legislation are still needed to ensure that no child shall suffer from malnutrition through the poverty of its parents, there are two Acts of Parliament, the Public Health Act of 1936 and the Education Act of 1921, which enable local authorities to provide supplementary nourishment, and this pamphlet sets out clearly what each local authority can do in its own area to solve this problem of child malnutrition.

\section{Rheumatism Research in Naval Training Centres}

THE Empire Rheumatism Council, in co-operation with the Admiralty, has set up a research foundation to investigate rheumatic disease in the training establishments of the Royal Navy. The research advisory committee has appointed a sub-committee consisting of Lord Horder, Sir William Willeox, Prof. George Hadfield, Dr. Mervyn Gordon and Dr. W. S. C. Copeman to supervise the work. Dr. C. A. Green, of the Bacteriological Department of the University of Edinburgh, is to take direct charge of the Foundation, and the Sir Halley Stewart Trust has appointed him to a research fellowship for three years for this task.

\section{National Nutrition Conference}

THE British Medical Association has decided to call a national conference on nutrition in its wider aspects-that is, in relation to national, including agricultural, policy-which will last three days, the dates provisionally selected being April 27-29. In addition to medical men, the conference will be representative of agricultural producers, home and over-seas, as well as of industry and education. The conference will take as its starting-point the recognized food needs of the individual, if health is to be maintained. Questions to be considered include : How far are these needs satisfied in Great Britain at the present time? What increases are required in the production of particular foodstuffs, either at home or in the Empire, to fill the gap? How can the necessary increases in consumption be best secured-through a system of family allowances; education, including propaganda; or otherwise?

\section{Micro-Methods for Medical Practitioners and Biologists}

IN conjunction with the Institute of Scientific Mieroscopy and Applied Opties of the University of Jena, Messrs. Carl Zeiss, Jena, are organizing a course of microscopy, microphotography, micro-cinematography, micromanipulation, Iuminescence microscopy, also absolute colorimetry, interferometry and spectral analysis, with particular reference to their significance in medicine and biology, to be held in Jena during March 27-April 1. During the lectures provided in the programme there will be talks by eminent authorities on optical methods. Of particular note is the fact that members will be offered the opportunity of widening their experience in the use of the apparatus and above all of trying out in practice the methods referred to during the lectures. Demonstrators and specialists will be available to answer all questions arising during the practical work in the laboratory. Further particulars and detailed programme can be obtained, in England, from Carl Zeiss (London), Istd., Mortimer House, Mortimer Street, W.1.

\section{New Comet and Super-nova}

A TELEGRAM from Copenhagen reports that Peltier, at Delphos, Ohio, discovered a comet on Jan. 20.000 U.T., its approximate position being R.A. $21^{\text {h }} 20 \cdot 0^{\mathrm{m}}$, Dec. $+28^{\circ} 0^{\prime}$, and its magnitude 8 . A later telegram states that Beljawsky saw the comet several hours earlier and found that its daily motion was $+5^{\mathrm{m}} 48^{\mathrm{s}}$ in R.A. and $-0^{\circ} 13^{\prime}$ in declina. tion. He gave the magnitude as 8 and estimated the tail to be about $1^{\circ}$. Other observations must have been available to Karstedt, who has computed the orbit and ephemeris given below ; as the observations are very rough, the orbit cannot be regarded as more than provisional.

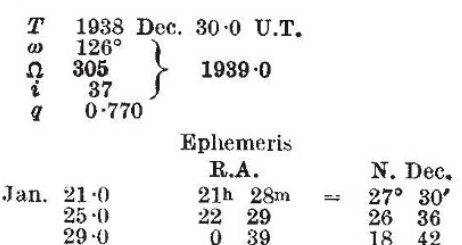

Zwicky reports a super-nova, mag. 17 on January I4, 12.5 on January 20 . It is $0 \cdot 6^{\prime}$ north-west of the nucleus of N.G.C. 4636.

\section{The Night Sky in February}

The moon is full on February 4 at $7 \cdot 9^{\text {h }}$ U.T. and new on February 19 at $8 \cdot 5^{\mathrm{h}}$. Lunar conjunctions with the planets occur as follows : with Mars on February 12 at $13^{\mathrm{h}}$; with Venus on February 15 at $3^{\mathrm{h}}$; with 
Jupiter on February 20 at $12^{\mathrm{h}}$ and with Saturn on February 23 at $6^{\mathrm{h}}$. Jupiter, which has been a conspicuous object in the evening skies for some months, is now approaching conjunction with the sun, and in the middle of the month sets at about $18 \frac{1}{2}^{\mathrm{h}}$. Mercury and Jupiter are close to each other on February 26. Saturn is an evening star in Pisces; in mid-February the planet sets at about $21 \frac{3 \mathrm{~h}}{4}$. Venus is the bright morning star rising before $5^{\mathrm{h}}$; its stellar magnitude is from $-4 \cdot 0$ to $-3 \cdot 9$. Mars rises some two hours before Venus, and is $5^{\circ}$ north of Antares on February 12. In mid-February, the constellation of Orion, which focuses attention on the most spectacular region of the whole sky, comes to the southern meridian at about $20^{\mathrm{h}}$. North preceding the Pleiades is the variable star, Algol, the light changes of which may be observed about $1 \frac{1}{2}$ hours before and after the following times of primary minima: February $9^{\mathrm{d}} 0 \cdot 1^{\mathrm{h}}, 11^{\mathrm{d}} 21 \cdot 0^{\mathrm{h}}$ and $14^{\mathrm{d}} 17 \cdot 8^{\mathrm{h}}$.

\section{Announcements}

Prof. G. Ingle Finch, professor of applied physical chemistry in the Imperial College of Science and Technology, was presented at the Belgium Embassy on January 23 with the order of Com. mander of the Order of King Leopold II, which has been conferred on him by King Leopold III for services rendered to science in Belgium during his term of office as Fondation Francqui professor in the University of Brussels during 1937-1938.

Prof. Victor F. Hess, formerly director of the Physical Institute of the University of Graz, has been appointed professor of physics in Fordham University, New York, as from November last. His address is : Department of Physics, Fordham University, New York City.

Mr. A. S. E. ACKERManN has been elected an honorary fellow of the Society of Engineers (Inc.) upon relinquishing the secretaryship of the Society, which he has held for thirty-one years.

IT is announced that a sale by auction will take place at Stevens Auction Rooms on February 10, at 12.30, of the important collection of scientific instruments, the property of the late Edward Milles Nelson. They include microscopes by Leitz, Powell \& Lealand, Swift, and other well-known makes, objectives, eyepieces, and other accessories, chemical balances and weights, a spectroscope, a telescope, drawing instruments; books, etc. Catalogues can be obtained from the Auctioneer, 38 King Street, Covent Garden, W.C.2.

AT the annual general meeting of the Royal Meteorological Society held on January 18, the following officers were elected : President, Dr. B. A. Keen; Treasurer, W. M. Witchell ; Secretaries, H. W. L. Absalom, W. Dunbar, and E. L. Hawke; Foreign Secretary, J. F. Shipley; Editor, Sir Gilbert Walker; New Members of Council, Lieut.-Commander T. R. Beatty, L. C. W. Bonacina, and G. Manley.
AT a meeting of the Chemical Society on January 23, it was announced that Dr. H. J. T. Ellingham is resigning from the office of honorary secretary. The Council of the Society has nominated Prof. G. M. Bennett as honorary secretary and Mr. F. P. Dunn as treasurer, for election at the annual general meeting on March 30. The Council has also accepted with regret the resignations of Prof. F. Challenger and Dr. S. Glasstone from the office of local representative for Leeds and Sheffield respectively, and has invited Dr. J. W. Baker (Leeds) and Sir. A. W. Chapman (Sheffield) to fill these vacancies.

Prof. Otto Lowwi has been appointed by the Fondation Francqui as a visiting professor for eight months to a Francqui chair in the University of Brussels. His address during that time will be : Fondation Universitaire, Il Rue d'Egmont, Brussels.

Prof. Otwo Meyerhof, For. Mem. R.S., of the Kaiser Wilhelm-Institut für Medizinische Forschung, Institut für Physiologie, Heidelberg, writes that his address from now on will be Institut de Biologie Physico-Chimique, 13, Rue Pierre Curie, Paris, 5.

Dr. Robert Feulaen, professor of physiological chemistry at Giessen, has been elected a member of the German Academy at Halle.

Prof. F. Pretrusky, of Bonn, has been elected honorary president of the International Academy for Forensic and Social Medicine.

Dr. Louis Martin, director of the Pasteur Institute of Paris, has been elected vice-president of the Paris Academie of Medecine and M. Gaston Louis Ramon, sub-director of the Institute, has been created a Commander of the Legion of Honour for his work on immunization against diphtheria and tetanus and combined inoculations.

ON the occasion of the International Water Exhibition and the inauguration of the Albert Canal, the eighteenth session of the Congress, known as the Journées médicales de Bruxelles, will be held at Liège on June 24-28 under the presidency of Prof. Ernest Renaux, member of the Belgian Royal Academy of Medicine. Further information can be obtained from the general secretary, Dr. René Bekkers, 141 rue Belliard, Brussels.

THe Annual Congress of the Ophthalmological Society of the United Kingdom will be held at the Royal Society of Medicine on April 20-22, when the subject for discussion will be the problems of refraction.

THE University of Groningen will commemorate on April 29-30 the one hundred and fiftieth anniversary of the death of Peter Camper, the celebrated physician, anatomist, obstetrician and artist, who was for ten years a professor at the University. 